\title{
Implementation Of School Based Management: a Study Of The Quality Of Learning In Junior High School
}

\author{
Jamiludin', Barlian $^{2 *}$, Susi Suhartini ${ }^{3}$, Nana Sumarna ${ }^{4}$ \\ Halu Oleo University, Southeast Sulawesi, Indonesia ${ }^{1}$ \\ \{barlianfkip@gmail.com $\left.{ }^{2}\right\}$
}

\begin{abstract}
The school reform models which is most important today is the schoolbased management model (SBM). The Indonesian government issued guidelines regarding the implementation of SBM in 2002. Schools that have implemented SBM are expected to increase the learning quality. This research is a quantitative research. An approach of research which reveals particular situations of social by properly reflecting reality, which is formed by words based on techniques for collecting and analyzing relevant data gathered from situations which is natural is called qualitative research. This study aims to provide an empirical picture of the quality of learning based on RPP instruments and learning implementation instruments by teachers. The researcher chose a junior high school in Konawe Regency, Southeast Sulawesi, Indonesia. The results show that there are several components that have not been implemented optimally, namely: the implementation of effective learning strategies / strategies, the use of learning resources / media in learning, the design of evaluation tools and monitoring tools to monitor the progress and learning outcomes of students in certain achievements. competencies, and make use of feedback for learners.
\end{abstract}

Keywords: based-schols management; junior high school, the quality of learning.

\section{Introduction}

transformation the direction of school management from centralization to decentralization is a school reform movement in order to increase the efficiency, equity and education quality. One of the most noteworthy models of school reform today is the school-based management model (SBM). SBM Models to be the most received as a major initiative of reform either to establish nations belonging New Zealand, UK, USA and Australia and increase states such as Hong Kong, Thailand and Indonesia. Dissimilar the approaches which are traditional, it was designed to supply a system which is accountability either the beneficiaries (students and parents), or the agents (teachers and makers of policy), to increase the education quality. Barrera-Osorio, Fasih, and Patrinos (2009: 15) stated that SBM is the authority decentralization to the level of school. Therefore, stakeholders are empowered by SBM under communities of school, increases participation in making the decision, and supplies chances to distribute power and authority at the level of school. A belief drives the 
SBM in which the responsible people for the children education, and the closest people in which implementation will happen are in the position which is best to decide how implementation have to take place at the level of school (Oswald, 2014).

In February 2001, particularly in Indonesia, the National Education Commission (Komisi Nasional Pendidikan/KNP) was established by the Central Government based on Law $22 / 1999$ in which decentralized occurs on education. The most KNP recommendations was to increase both councils of educational at level of district or school at level of school. The Education Council formation was recommended by the Commission (Dewan Pendidikan) at level of district and councils of school (Dewan Sekolah/Komite Sekolah) at level of school to increase the national education quality (Bandur, 2012). The decentralization of education policies that give school authority to increase the education quality have an impact on improving principles of democratic, participation of community, equity, and diverse interests accommodation and necessity of the area (Departemen Pendidikan Nasional, 2001: 26). Research relevant to the results of this study is research conducted by Pasaribu (2017). The result of the research is an increase in the quality of education in schools which needs to be supported by managerial school principals. Developing schools need to progress from year to year. Because of that, a good relationship between teachers that needs to be created will establish a conducive and pleasant working climate and atmosphere. Likewise, the arrangement of physical appearance and school management that needs to be fostered so that the school becomes an educational environment that can foster creativity, discipline, and enthusiasm for learning of students. It is within this framework that the implementation of SBM is felt. To implement effective and efficient school management, the principal needs to have knowledge of leadership, planning, and school and education views. Furthermore, school principals are required to carry out their function as school managers in improving the teaching and learning process, by conducting classroom supervision, fostering, and providing positive suggestions to teachers. In addition, school principals must also exchange ideas, brainstorm, and conduct comparative studies between schools to absorb leadership tips from other school principals. In implementing SBM effectively and efficiently, teachers must also be creative in improving classroom management. Teachers are role models and role models with the students in the class. Therefore, teachers need to be ready with all obligations, both management and preparation of material content.

\section{Method}

An approach of research that covers a certain situation of social by portraying exactly, presented by word per word based on collection of data and techniques of analysis which is relevant gathered from situations which is natural is called qualitative research (Satori \& Komariah, 2011). Qualitative research is not only an attempt to describe data but the description is the result of data collection sohih required qualitative in depth interview, observation, participation, document study, and by doing triangulation. Also the description is based on valid data analysis, from data display data reduction, data reflection, emic study and ethics to data and to conclusion that must have high trust based on dependability, credibility, transferability, and confirmability.

The subject of this research is related to the SBM implementation in improving the quality of learning in one of the junior high schools of Konawe District, South east Sulawesi, Indonesia. These subjects include: principals, vice principals, and interviewed teachers conducted by purposive sampling. 


\section{Result and Discussion}

Schools that are in the research location have 1 principal, 1 vice principal, 14 teachers, and 3 administrative staff. The research findings from the preparation of the lesson plan are based on the lesson plan quality prepared by teacher before doing the learning process. The assessment is based on the descriptor of each measured indicator.

Preparation of the lesson plan is an integral part of a process of learning in the classroom. Teachers should be able to develop a learning plan that fits the level of characteristics and depth of material to the student's needs. The description of each component and indicator of APKG I is shown in the table below.

Table 1. of the learning implementation analysis

\begin{tabular}{|c|c|c|c|}
\hline No. & Components and indicators & score & category \\
\hline \multicolumn{4}{|c|}{ Learning Activities } \\
\hline 1 & $\begin{array}{l}\text { Preliminary activities } \\
\text { a. Carry out regular class assignments } \\
\text { b. Perform apperception before starting learning } \\
\text { c. Deliver the competencies to be achieved in the } \\
\text { activity plan } \\
\text { d. Starting learning activities }\end{array}$ & 4.0 & Very good \\
\hline 2 & 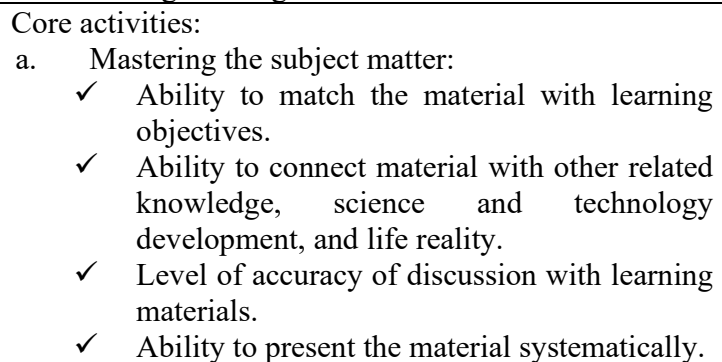 & 3.0 & good \\
\hline & 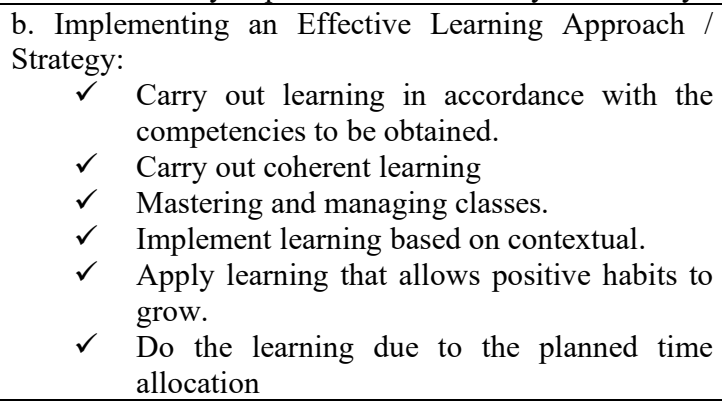 & 2.6 & enough \\
\hline & $\begin{array}{cl}\text { c.Utilizing resources/media learning: } \\
\checkmark & \text { Showing skills in the use of learning media } \\
\checkmark & \text { Generate an interesting message. } \\
\checkmark & \text { Involve students in making and utilizing } \\
& \text { learning resources / learning media }\end{array}$ & 2.6 & enough \\
\hline & $\begin{array}{l}\text { d. Triggering and Maintaining Student Involvement } \\
\text { in Learning: } \\
\checkmark \text { Fostering students active participation } \\
\text { through the teachers, students interaction, } \\
\text { learning resources. }\end{array}$ & 3.0 & good \\
\hline
\end{tabular}




\begin{tabular}{|c|c|c|c|c|}
\hline & & $\begin{array}{ll}\checkmark & \text { Respond positively to participation of } \\
\text { students. } \\
\checkmark & \text { Showing an open attitude towards responses } \\
\text { of student and showing a conducive } \\
\text { relationship of interpersonal } \\
\checkmark \\
\text { Fostering the joy and anthropism of students } \\
\text { in learning }\end{array}$ & & \\
\hline & e. & $\begin{array}{l}\text { Using Correct and Right Language in Learning: } \\
\checkmark \quad \text { Use a clear and fluent spoken language. } \\
\checkmark \quad \text { Use good and correct written language. } \\
\checkmark \quad \text { Deliver messages with the appropriate style. }\end{array}$ & 3.8 & Very good \\
\hline 3 & \multicolumn{2}{|r|}{$\begin{array}{l}\text { Closing activities } \\
\text { a. Reflect or create a summary by involving students } \\
\text { b. Follow up by providing directions, or activities or } \\
\text { tasks as enrichment }\end{array}$} & 3.0 & good \\
\hline \multicolumn{5}{|c|}{ Assessment activities } \\
\hline & a. & $\begin{array}{l}\text { Designing Evaluation Tools for Measuring } \\
\text { Progress and Success of Learners: } \\
\checkmark \\
\text { The suitability of the technique and the type } \\
\text { of assessment (oral, written test, } \\
\text { demonstration test) in accordance with the } \\
\text { learning objectives. } \\
\text { The test tool is designed to be able to } \\
\text { measure the learning progress of learners } \\
\text { from the cognitive, affective and } \\
\text { psychomotor aspects. } \\
\checkmark \text { The design of portfolio assessment of learners } \\
\text { at least } 1 \text { time per semester. } \\
\checkmark \text { The results of the previous assessment } \\
\text { (formative and final examination) are used } \\
\text { for improvement program purposes }\end{array}$ & 2.3 & deficient \\
\hline & b. & $\begin{array}{l}\text { Using various assessment strategies and methods to } \\
\text { monitor the progress and learning outcomes of } \\
\text { learners in achieving certain competencies: } \\
\checkmark \quad \text { Using authentic assessment techniques } \\
\text { (quizzes, oral questions, assignments) to } \\
\text { monitor students' learning progress. } \\
\checkmark \quad \text { Using formative assessment techniques and } \\
\text { final exams are structured to measure } \\
\text { learners' learning outcomes in the cognitive, } \\
\text { affective and psychomotor aspects. } \\
\checkmark \text { Implement portfolio assessments in the form } \\
\text { of structured tasks. } \\
\checkmark \text { Use assessment tools that are appropriate to } \\
\text { the learning objectives and teaching materials } \\
\text { as outlined in the lesson plan. }\end{array}$ & 2.3 & deficient \\
\hline & c. & $\begin{array}{l}\text { Utilize various assessment results to provide } \\
\text { feedback for learners: } \\
\checkmark \quad \text { Using the results of the assessment analysis } \\
\text { to identify the basic / simple topics that are } \\
\text { easy, medium and difficult to know the } \\
\text { strengths and weaknesses of each learner for } \\
\text { remedial and enrichment purposes. }\end{array}$ & 2.3 & deficient \\
\hline
\end{tabular}




$\checkmark \quad \begin{aligned} & \text { Use assessment results to refine the design } \\ & \text { and implementation of learning. }\end{aligned}$
$\checkmark \quad \begin{aligned} & \text { Reporting the progress and learning outcomes } \\ & \text { of learners to parents, friends and teachers for }\end{aligned}$
learners as a reflection of learning.
$\checkmark \quad \begin{aligned} & \text { Utilize assessment results effectively to } \\ & \text { identify potential strengths, weaknesses, } \\ & \text { challenges and problems for professional } \\ & \text { improvement in supporting the learning } \\ & \text { process }\end{aligned}$

The above findings indicate that the results of teacher teaching ability assessment in general are in good category, but not optimal. Assessment of the learning plan on its principles is the basis or reference of teachers in implementing the learning process, need to be improved quality. This condition also affects the ability of teachers to teach in front of the class. As a school that has implemented SBM, it is assumed that the whole teaching and learning process will give a better quality improvement. One that emphasizes the construction of the lesson plan is to refer to the context of syllabi, indicators and learning activities.

This condition is reinforced by a statement from the principal (Mr.Abdul Hakim) who suggests that "..in preparing syllabus can use a format appropriate to the needs of educational unit. In formulating basic competence sequences, subject matter or learning materials, learning activities, indicators and so on can be defined by each educational unit, insofar as it does not reduce the components in the syllabus"

Furthermore, in the implementation of the learning process, seen the existence of some conditions that have not provided an optimal response, especially in some indicators assessed. Some things of concern in the process of implementation of learning, among others (1) the ability of teachers in linking the material with other relevant knowledge, especially between material with real life, often done without including the concept of science and technology and the implementation process is not systematic. In fact, sometimes not in accordance with the planned lesson that has been prepared; (2) class management is good, but there needs to be creation of condition that able to develop positive attitude of student in learning. This is an important point because the learning process takes place "bland" because it focuses on mastery of the material. There needs to be an atmosphere that responds to positive habits for students according to the material being taught.

Mrs. Lisnawati (teacher) stated that " ...in the implementation of classroom learning activities, we generally have been able to manage the class well, but if I leave class and give discussion assignment, there is a commotion and students often move around during the learning process Teaching takes place".

In add by Mr. Abdul Hakim, that "... in the implementation of learning activities in the classroom by the teacher occurs a problem, the atmosphere in the class sometimes rowdy and students sometimes out of the classroom, because teachers out of class for learning affairs, for example, Go to the teachers' room to take attendance list or textbook, etc. While in another aspect, the teacher has done the learning activity well "; and (3) it is necessary teacher's creativity to trigger and maintain student involvement in learning process. The existing process shows that, teachers teach in accordance with habits that are patterned in a learning process that cascade, in accordance with the flow of learning materials. 


\section{Conclusion}

The use of lesson plans and the implementation of learning in an effort to improve the learning quality in the schools by applying SBM is in principle good, but not optimal. Several components that need to be improved include in the context: implementing an effective learning approach / strategy, utilizing learning resources / media in learning, designing evaluation and monitoring tools to monitor the progress and learning outcomes of students in achieving certain competencies, and utilizing feedback for student. Research findings indicate that the results of the teacher's teaching ability assessment are generally in the good category, but not optimal. In principle, the assessment of the learning plan which is the basis or reference for the teacher in carrying out the learning process, needs to be improved in quality. This condition also affects the ability of teachers to teach in front of the class. As a school that has implemented SBM, it is hoped that the entire teaching and learning process will improve in quality. One thing that emphasizes the construction of lesson plans is referring to the context of the syllabus, indicators and learning activities. This condition was reinforced by a statement from the principal (Mr. Abdul Hakim) who stated that "... in compiling the syllabus, a format that suits the needs of the educational unit can be used. Furthermore, in the implementation of the learning process, it was seen that there were several conditions that had not provided an optimal response, especially on several indicators that were assessed, the process was not systematic. Sometimes it doesn't even fit the lesson plan that has been prepared.

\section{References}

[1] Departemen Pendidikan Nasional, 2001. Menuju Pendidikan Dasar Bermutu dan Merata: Laporan Komisi Nasional Pendidikan. Depdiknas: Jakarta.

[2] Indriyanto, B., 2004. School-Based Management: Issues and hopes toward decentralization in education in Indonesia. retrieved from http:// www.worldedreform.com

[3] Ingersoll, R., \& Perda, D. (2010). Is the supply of mathematics and science teachers sufficient? American Education Research Journal. 47, 563-594.

[4] Kennedy. M.J., Hirsch, S.E., Rodgers, W.J., Bruce, A., \& Lloyd, J.W. (2017). Supporting high school teachers' implementation of evidence-basedclassroom management practices. Teaching and Teacher Education. 63 (2017), 45-57

[5] Lane, K. L., Menzies, H. M., Oakes, W. P., Zorigian, K., \& Germer, K. A. (2014). Professional development in EBD: What is most effective in supporting teachers. In P. Garner, J. Kauffman, \& J. Elliot (Eds.), The handbook of emotional \& behavioral difficulties (2nd ed., Vol. 24, pp. 251-293). Thousand Oaks, CA: Sage.

[6] Ministry of National Education, (2004). Educational and School Councils. Retrieve from http://www.dikdasmen.depdiknas.go.id

[7] Oswald, L. J. (2014). School-Based Management: Rational and Implementation Guidelines. Palmer, AK: Wordsworth LLC Publishing

[8] Pasaribu, Asbin. 2017. Implementasi Manajemen Berbasis Sekolah Dalam Pencapaian Tujuan Pendidikan Nasional Di Madrasah. Dalam Jurnal EduTech Vol. 3 No. 1 Maret 2017. Halaman 12-34.

[9] Satori, D. \&Komariah, A. (2011) Metode penelitian Kualitatif . Alfabeta: Bandung 
[10] Schlegel, J. A., (2000). A Descriptive Case Study of Site-Based Management in a Small Urban School District in South Central Pennsylvania. Retrieved from http://0wwlib.umi.com.library.newcastle.edu.au.

[11] Sutherland, K. S., Denny, R. K., \& Gunter, P. L. (2005). Teachers of students with emotional and behavioral disorders reported professional development needs: Differences between fully licensed and emergency-licensed teachers. Preventing School Failure. 49(2), 41-46.

[12] Sutton, R., Mudrey-Camino, R., \& Knight, C. C. (2009). Teachers' emotion regulation and classroom management. Theory into Practice. 38, 130-137.

[13] Barrera-Osorio, F., Fasih, T., \& Patrinos, H. A. (with Santibáñez, L.). (2009). Decentralized decisionmaking in schools: The theory and evidence on school-based management. Washington, DC: World Bank. Retrieved from http://siteresources.worldbank.org/EDUCATION/ Resources/2782001099079877269/547664-1099079934475/547667-1145313948551/

[14]Decentralized_decision_making_schools.pdf 